\title{
Slit Homolog 1 Protein
}

National Cancer Institute

\section{Source}

National Cancer Institute. Slit Homolog 1 Protein. NCI Thesaurus. Code C126784.

Slit homolog 1 protein (1534 aa, 168 kDa) is encoded by the human SLIT 1 gene. This protein plays a role in the development of blood vessels and the differentiation of neurons. 